\title{
KORZYSTANIE Z BIBLIOTEK JAKO FORMY RELACJI -ANALIZA KONCEPCJI TEORETYCZNEJ Z WYKORZYSTANIEM TRIANGULACJI METOD BADAWCZYCH
}



Magdalena Paul jest doktorem nauk humanistycznych w zakresie bibliologii i informatologii, absolwentką i pracownikiem Wydziału Dziennikarstwa, Informacji i Bibliologii Uniwersytetu Warszawskiego. Ukończyła także studia II stopnia w Instytucie Socjologii UW.

Jej zainteresowania badawcze koncentrują się na: kompetencjach cyfrowych, kulturowej i społecznej funkcji bibliotek, ocenie wpływu społecznego bibliotek oraz zastosowaniu metod badań społecznych w LIS.

Wybrane publikacje: Czym jest czytanie: intuicje i definicje. Kultura Popularna (2016, wraz z M. Kisilowską); Wpływ społeczny bibliotek publicznych - badania i dobre praktyki. Zarzadzanie Biblioteka (2016); Współczesna polska bibliologia - „Słownik pracowników książki polskiej" w liczbach i w perspektywie sieciowej. Toruńskie Studia Bibliologiczne (2017); Information literacy of Polish students in social sciences and humanities. ZIN - Studia Informacyjne (2018, wraz z E. Głowacką i M. Kisilowską).

SŁOWA KLUCZOWE: Bibliotekarze. Biblioteki publiczne. Metodologia badań. Triangulacja. Użytkownicy bibliotek. Wpływ społeczny bibliotek publicznych.

ABSTRAKT: Tezy/cel artykułu - Celem artykułu było pogłębienie refleksji na temat zastosowania triangulacji na przykładzie badania wpływu społecznego bibliotek publicznych w województwie mazowieckim. Metody badań - W części jakościowej zastosowano procedury konstruktywistycznej teorii ugruntowanej, a dane zebrano za pomocą IDI. W ramach modułu ilościowego przeprowadzono sondaż na próbie losowej. Wyniki - Korzystanie z bibliotek można opisać poprzez relację łączącą bibliotekarzy i użytkowników. Przebiega 
ona na różnych poziomach, które mogą się przecinać. Z perspektywy użytkownika największe znaczenie dla relacji ma podaż czasu wolnego, alternatywne źródła korzyści oraz odwzajemnienie zaangażowania. Biorąc pod uwagę większą zbiorowość dla sposobów i intensywności korzystania z bibliotek kluczowe znaczenie mają zmienne społeczno-demograficzne. Wnioski - Zbieżność obu rodzajów danych umożliwiła lepsze zrozumienie problemu badawczego i pogłębienie wniosków.

\section{WSTĘP}

Czytelnicy, użytkownicy, klienci - te tradycyjnie już przyjęte określenia osób korzystających z bibliotek różnią się między sobą naciskiem na czynności wykonywane przez nich w bibliotekach i usługową rolę tych placówek. Wszystkie trzy mają jednak wspólną cechę - są niewystarczające, nie oddają w pełni spektrum relacji, zależności, które każda z osób może nawiązać z biblioteką jako instytucją, jej pracownikami i innymi ludźmi, którzy współtworzą to miejsce. W niniejszym artykule podjęto próbę opisania korzystania z bibliotek właśnie jako relacji. Na tym przykładzie podniesiono również kwestię metodologii badania użytkowania bibliotek i zastosowania triangulacji metod dla lepszego zrozumienia problemu badawczego.

W pierwszej części artykułu zarysowano kontekst istotny dla pojęcia relacji z biblioteką - odniesiono się do partycypacyjności, tj. uczestnictwa w bibliotece i budowanego dzięki kontaktom z bibliotekarzami kapitału społecznego. Następnie omówiono metodologię badania. Część zasadniczą stanowi przedstawienie wyników badania, przy czym położono nacisk na to, w jaki sposób dane gromadzone dzięki metodom jakościowym i ilościowym wzajemnie się tłumaczą i uzupełniają. Na koniec odniesiono się ogólnie do roli triangulacji w badaniach wpływu społecznego bibliotek, w które wpisuje się koncepcja relacji z biblioteką.

\section{KONTEKST BADANIA}

W ciagu ostatnich kilkunastu lat dokonało się istotne przejście w myśleniu o roli użytkowników biblioteki w budowaniu społeczności wokół tych instytucji kultury oraz rozwijaniu jej usług. Zmianę tę wyrazić można jako from collection to connection. Ten prosty zwrot obrazuje, że środek ciężkości w myśleniu o bibliotekach zostaje przeniesiony ze zbiorów na społeczność (około)biblioteczną. Wzmocnienie trendu współuczestnictwa użytkowników w tworzeniu biblioteki wiąże się z szerszymi tendencjami, takimi jak:

- demokratyzacja kultury - w ramach której nacisk kładziony jest nie tylko na dostęp do kultury, ale również jej społeczny odbiór, remiksowanie i redystrybucję, 
- przemiany komunikacji - przejście od komunikacji jednokierunkowej do dialogu z użytkownikami,

- podejście prosumenckie - użytkownik jest nie tylko „konsumentem”, ale jednocześnie także „producentem” np. treści w mediach społecznościowych dotyczących biblioteki, polityki i strategii bibliotecznej (Hvenegaard Rasmussen, 2016, pp. 546-548).

Współuczestnictwo użytkowników jest również jednym z kluczowych elementów koncepcji biblioteki 2.0 (Gmiterek, 2012, s. 125-130; Jaskowska i Dudczak, 2007, s. 359-360). W porównaniu z biblioteką partycypacyjną w tym podejściu większy nacisk kładzie się na rolę nowych technologii informacyjno-komunikacyjnych.

Wyniki badań Catherine A. Johnson, realizowanych w USA i w Kanadzie od 2006 r. wskazuja że kontakty z bibliotekarzami mogą mieć pozytywny wpływ na tworzenie kapitału społecznego. Większość bibliotekarzy, z którymi przeprowadziła wywiady w trzech filiach $\mathrm{w}$ jednym $\mathrm{z}$ dużych miast w środkowej części Stanów Zjednoczonych, bardzo ceniła relacje nawiązane z użytkownikami, część jednak odczuwała dyskomfort, gdy stawały się one zbyt bliskie. Problemem w tym przypadku była obawa, że użytkownicy za bardzo opierając się na pomocy bibliotekarza, utracą samodzielność (Johnson, 2012, pp. 55-56). Badanie wykazało, że na tworzenie się kapitału społecznego w bibliotekach największy wpływ miało:

- nawiązanie stosunków i budowanie zaufania pomiędzy pracownikami bibliotek i użytkownikami,

- wspomaganie użytkowników w dostępie do zasobów zarówno w bibliotece, jak i poza nią (np. pomoc w oddawaniu książek oferowana przez bibliotekarzy starszym sąsiadom),

- specjalna pomoc udzielana przez pracowników biblioteki użytkownikom,

- korzystanie z biblioteki jako miejsca spotkań nieformalnych,

- postrzeganie biblioteki jako bezpiecznego miejsca,

- korzystanie z biblioteki jako miejsca, gdzie można poznać innych ludzi, co zmniejsza izolację społeczna,

- poczucie wspólnej własności społecznej i dumy z biblioteki (Johnson, 2012, pp. 56-60).

Johnson przeprowadziła także badanie poświęcone tej tematyce w Kanadzie (wraz z Matthew Griffisem). Badacze zidentyfikowali cztery sposoby, na które biblioteki mogą wzmacniać proces budowania kapitału społecznego:

- hub społeczno-informacyjny,

- integrator dla nowych członków społeczności i mniejszości,

- symbol lokalnej społeczności, obywatelskości i autonomii,

- wsparcie dla większej sieci miejsc i ludzi (Johnson \& Griffis, 2014a, pp. 102-106). 
Biorąc pod uwagę powyższy kontekst i fakt, że do tej pory w Polsce nie prowadzono szeroko zakrojonych analiz $\mathrm{w}$ tym zakresie, wydaje się istotne, aby zbadać, w jaki sposób użytkownicy postrzegają swoje kontakty $\mathrm{z}$ bibliotekami i bibliotekarzami.

\section{METODOLOGIA BADANIA}

Jednym z głównych celów badania, zarówno modułu jakościowego i ilościowego, było opisanie sposobów korzystania z bibliotek publicznych i doświadczeń użytkowników z tym związanych.

W części jakościowej badania skorzystano z założeń i procedur teorii ugruntowanej w modelu konstruktywistycznym, którego reprezentantką jest Kathy Charmaz (Charmaz, 2013). Cechą wyróżniającą tego podejścia, podobnie jak w klasycznej wersji teorii ugruntowanej (stworzonej przez Anselma Straussa oraz Barneya Glasera w latach 60. XX w., a następnie rozwijanej wraz z Juliet Corbin) jest założenie, że teoria tworzona jest na podstawie zebranych danych, "gruntuje się" w terenie badawczym. To podejście metodologiczne jest więc odwróceniem $\mathrm{zw}$. podejścia pozytywistycznego, w którym teoria konstruowana jest na początku procesu badawczego, a następnie testowana na podstawie danych.

Dane zebrano techniką pogłębionych wywiadów indywidualnych. Zastosowano dobór celowy. Rozmowy przeprowadzono z 11 użytkownikami warszawskich bibliotek publicznych. Podstawowym kryterium doboru był sposób korzystania $\mathrm{z}$ uług bibliotecznych (w próbce znalazły się więc osoby intensywnie korzystające z bibliotek od dłuższego czasu, angażujące się w działalność bibliotek, jak i użytkownicy okazjonalni lub którzy dopiero niedawno zetknęli się z usługami bibliotek). Biorąc pod uwagę cechy demograficzne - było to sześć kobiet i pięciu mężczyzn. Najmłodsza osoba miała dwadzieścia trzy lata, a najstarsza osiemdziesiąt sześć. Uczestnicy badania różnili się między sobą wykształceniem, statusem materialnym, aktywnością zawodową (osoby pracujące w różnych sektorach, bezrobotne, na emeryturze). W procesie anonimizacji wywiadów nadano im fikcyjne imiona zaczynające się od kolejnych liter alfabetu (od A do K; charakterystyki badanych zostały zamieszczone w aneksie dołączonym do artykułu). Wywiady przeprowadzano sukcesywnie aż do osiągnięcia tzw. wysycenia. Po stworzeniu wstępnych kategorii teoretycznych dokonano również teoretycznego pobrania próbki - w tym celu powrócono do kilkorga z badanych wcześniej osób, aby zebrać dalsze informacje, które mogłyby wypełnić lub zweryfikować kategorie.

W czasie wywiadów zadawano możliwie jak najszersze pytania - jak wygląda „historia” użytkowania bibliotek przez uczestnika badania lub jaki jest stosunek do biblioteki, z której dana osoba korzystała najczęściej. Pytano również o ulubioną i idealną bibliotekę, pierwsze doświadczenia 
w korzystaniu z tych instytucji kultury i obecny sposób ich użytkowania, a także o korzyści wynikające z kontaktów z bibliotekami. Pytania zadawano w sposób dostosowany do rozmówcy i charakteru rozmowy.

Celem części ilościowej było z kolei określenie, na ile przytaczane przez pojedynczych rozmówców w module jakościowym badania sposoby korzystania z bibliotek i odczuwane korzyści uwidaczniają się w szerszej zbiorowości użytkowników bibliotek publicznych. Aby zrealizować ten cel, przeprowadzono badanie sondażowe wśród pełnoletnich użytkowników 38 mazowieckich bibliotek publicznych w okresie między lutym a czerwcem 2017 r. Dobór próby był losowy. Operat losowania został ograniczony do osób, które w momencie przeprowadzania badania użytkowały daną bibliotekę (ankieta audytoryjna). Zebrano odpowiedzi od 1098 osób, niestety, badana próba nie jest reprezentatywna w stosunku do populacji pod względem wieku i typu miejscowości zamieszkania.

W kwestionariuszu ankiety uwzględniono pytanie dotyczące aktywności podejmowanych w bibliotekach. Respondenci wskazywali, czy wykonywali działania z przedstawionej 23-punktowej listy. Jako zmienne wyjaśniające przyjęto częstotliwość korzystania z bibliotek, korzystanie z innych instytucji kultury oraz mediów (książki, prasy i innych mediów), a jako zmienne kontrolne - wiek, sytuację finansowa, wielkość gospodarstwa domowego oraz wielkość miejscowości zamieszkania (kwestionariusz ankiety dołączono do artykułu $\mathrm{w}$ formie aneksu).

Aby określić związek pomiędzy zmiennymi, wykorzystano test chi-kwadrat ${ }^{1}$ (Test zgodności chi-kwadrat, 2016). Dodatkowo, aby zwiększyć pewność twierdzeń dotyczących związku między zmiennymi, użyto także korelacji rangowej Spearmana ${ }^{2}$ (rho Spearmana, @S) (Lissowski, Haman i Jasiński, 2011, s. 101, 118-119). W przypadku zmiennych wyjaśnianych przedstawionych na skalach mocnych, wykorzystywano metodę porównywania średnich (regresję średnich) w podgrupach. Wartość związku w tym przypadku określa współczynnik $\eta^{2}$ (Lissowski i in., 2011, s. 40-41). Dla określenia istotności testów przyjęto poziom $\mathrm{p}=0,05$. Dla określenia rzetelności baterii pytań użyto alfy Cronbacha3. Współczynnik ten pozwala stwierdzić, czy występuje wewnętrzna spójność, opisuje stopień, $\mathrm{w}$ jakim wszystkie pozycje $\mathrm{w}$ teście mierzą to samo pojęcie albo konstrukt (Hryniewicz, 2016). Wszystkie obliczenia i testy przeprowadzono w programie SPSS Statistics 20.

\footnotetext{
1 Test chi-kwadrat jest najbardziej rozpowszechnionym testem nieparametrycznym. Służy do porównywania zaobserowanego rozkładu zmiennej z rozkładem teoretycznym, jak również sprawdzania równoliczności grup.

${ }^{2}$ Korelacja rangowa Spearmana, w przeciwieństwie do np. równie rozpowszechnionej korelacji, Pearsona, może być obliczana także dla zmiennych na skali porządkowej.

${ }^{3}$ Współczynnik alfy Cronbacha obliczono dla całej kafeterii 23 podpunktów pytania nr 3 oraz dla podgrup wyróżnionych zgodnie z koncepcją teoretyczną poziomów relacji. Zmienne eliminowane były, jeśli kierunek korelacji był odwrotny w stosunku do całej podgrupy.
} 


\section{KORZYSTANIE Z BIBLIOTEK JAKO FORMA RELACJI}

Uczestnicy badania opisywali korzystanie przez siebie z bibliotek i działania $\mathrm{w}$ nich podejmowane $\mathrm{w}$ różnorodny sposób, np. jako przychodzenie, wpadanie do bibliotek; jako „grzebanie po półkach” lub „wchodzenie między regały". Jeżeli dokładniej przeanalizować określenia, które pojawiały się w ich wypowiedziach, można wysunąć wniosek, że opisywali oni użytkowanie bibliotek jako formę relacji. Pojęcie relacji ${ }^{4}$ traktowane jest bardzo szeroko jako związek zachodzacy między ludźmi lub grupami społecznymi (Relacja, b.d.). Relacja z biblioteką jest więc de facto relacją między użytkownikami a bibliotekarzami i - rzadziej - innymi użytkownikami biblioteki. Potrzebne jest przy tym zastrzeżenie, że w czasie zadawania pytań nie używano określeń tego typu, pojawiały się one natomiast swobodnie w wypowiedziach prawie wszystkich badanych. Dla przykładu podać można wypowiedź Henryka:

Henryk: Zawsze lubitem biblioteki i pierwszy kontakt, to miatem bardzo fajna biblioteke w szkole podstawowej. [...] Także taki pierwszy kontakt z biblioteka to jest to. [...] Bardzo ta wspótpraca się tak poszerzyła. [...]. Ja nawiazałem bardzo serdeczne relacje w bibliotece. Pewnie to wykracza poza ramy tego wywiadu, ale mam... Zaczynajac od kontaktów czytelnik-pracownik biblioteki, z kilkoma osobami, mam wrażenie, że się zaprzyjaźniliśmy, bo odkryliśmy, że łacza nas bardzo podobne zainteresowania.

Ponadto dwoje spośród badanych, Celina i Emil, użyli do opisu swojej relacji z bibliotekami odniesienia do rodziny.

Celina: Do całego zespołu jestem przywiazana i każda zmiane przeżywam, jakby to było tak w mojej rodzinie na przykład. I no najbardziej na poczatku byłam, że tak powiem, nie wiem, czy to można powiedzieć zaprzyjaźniona, no bo to jest takie nietypowe słowo, ale tak "zwiazana", też złe. Najbardziej, że tak powiem, się trzymałam tak z pania [...].

Emil: Tak, tak, tam jest bardzo miła obstuga, panie sa bardzo fajne, więc tam jakoś czuje się zwiazany. Zreszta, to troche jak rodzina, bo chodze tam już chyba, nie wiem, ze dwadzieścia lat, więc... [Śmiech]. To właściwie, kiedy dzwonię do pań, to one wiedza po nazwisku, kim jestem i jakoś mnie kojarza, no więc, no, trochę jak u siebie w domu wyglada, czy coś.

\footnotetext{
${ }^{4}$ Pojęcie relacji ma bogatą historię stosowania w naukach społecznych. Podjęto decyzję o nieodwoływaniu się w czasie budowania koncepcji do konkretnej teorii relacji społecznych, aby nie ukierunkowywać analizy w określoną stronę. Pewną inspiracją w myśleniu o relacjach z bibliotekami była teoria wymiany, zwłaszcza Homansa i Blaua (Turner, 2012, s. 301-324). Stąd też w opisie płytkiej relacji z biblioteka, użyto określenia „transakcja”.
} 
Mimo że tych dwoje badanych korzystało z bibliotek w odmienny sposób (Celina od wielu lat była wolontariuszką, a Emil wyłącznie wypożyczał książki z zakresu literatury faktu lub naukowe), można powiedzieć, że ich relacja z bibliotekami ma pewne wspólne właściwości - wydaje się naturalna, niewymuszona, cechuje ją osobisty charakter. W opisach lubianych przez uczestników lub idealnych wyobrażeniach bibliotek znajduje się wiele wątków dotyczących bliskości tego miejsca, spersonalizowania usług, cichej, spokojnej, intymnej atmosfery.

Na podstawie opisów korzystania z bibliotek wyróżnić można różne poziomy relacji. Poziom płytki polegałby na korzystaniu wyłącznie z materiałów bibliotecznych, wypożyczaniu i zwracaniu książek, czytaniu gazet itp. W trakcie tego rodzaju spotkania następuje komunikacja między użytkownikiem a bibliotekarzem, ale jest ona ograniczona do konkretnego celu, może umacniać relację, ale nie pogłębia jej poziomu. Użytkownik jest bardzo samodzielny w swoich działaniach, nie polega na pomocy bibliotekarza. Celina obserwowała takie transakcje w ramach swojej pracy wolontariackiej, a Emil korzystał z biblioteki wyłącznie w ten sposób.

Celina: Jak przychodzisz sobie, no, nie, z takim statystycznym X-em, człowiekiem tam takim, to przychodzisz sobie, mówisz, że nazywasz się tak i tak, chcesz taka ksiażkę, cośtam tego i liczysz tylko pania, która ci tę ksiażkę tutaj. Koniec, nie? I tak, powiedziałabym, że jak na moje oko to z osiemdziesiąt procent tak pewnie robi, tak? Że nawet nie zamieni stowa, tylko tak hop, hop, to, tamto. To czasami zamieni słowa, że się przedstawi, tak? I powie ewentualnie czego potrzebuje, ale tak ograniczamy tę komunikacje do minimum, tak?

Emil: Nie ujmując nikomu niczego, ale to, co szukam, to sa zazwyczaj jakieś takie dosyć mało znane, niemainstreamowe rzeczy, więc na ogót nie oczekuję, że ludzie będa coś o tym wiedzieli. [...]. No, wie pani, to jest czysto utylitarne, nie ma żadnych innych powodów. Ja po prostu chodzę w ramach swojego interesu, chce dostać ksiażke, po to tam chodzę.

W wypowiedzi Emila widać dokładnie, co charakteryzuje relację na poziomie płytkim - jest to indywidualizm, nastawienie na siebie i realizowanie własnych celów. Obie strony relacji, pozostają przy tym neutralne, to znaczy ich działania nie wykraczają poza niezbędne do wykonania transakcji minimum.

Natomiast w przypadku relacji pośredniej jedna strona, bibliotekarz, angażuje się w nią aktywniej. Przypisać należałoby do tej relacji wszelkie działania polegające na udzielaniu użytkownikom porad, pomocy w zakresie zbiorów i udostępniania urządzeń do pracy, nauki itd. Nie wykracza to oczywiście poza standardy pracy bibliotecznej, ale z perspektywy użytkownika, co pojawiało się w wypowiedziach, jest czymś dodatko- 
wym, ma szczególną wartość. Umiejętność doradzenia użytkownikowi jest też postrzegana jako wyjątkowy talent, kwestia predyspozycji psychicznych i rozwiniętych kompetencji.

Grzegorz: To jest pierwsze primo, a drugie primo to pani kierownik jest niesamowita. Niesamowita. Pomoc, jaka od niej uzyskałem, to... Po prostu ona... Bo ona wiedziata, gdzie co jest. To jest, wie pani, tak jak w internecie. Najważniejsza jest wiadomość, ale trzeba umieć ja znaleźć. I ona wiedziała, gdzie co jest, $i$ ona mi podsuwała nieraz konkretne tytuły. "A może by pan to...". [...] Ale bardzo dużo mi pomogła, no i... Sama życzliwość jej. Dla mnie to jest ona w ogóle geniusz [...].

Barbara: Maja chyba coś z psychologii w sobie, potrafia... Jak przyjdę i mówię: "Boże, coś mi się chce czytać, ale naprawde nie wiem co" i zawsze mi doradza takie coś naprawdę fajnego.

Karolina: Przychodzac tutaj, poszukując jakiejś nowej, fajnej ksiażki, pani [...] od razu wie, która mi się spodoba i nawet z tych nowości, czy ktoś odda, potrafi mi doradzić i podsunać. I powiem szczerze, że w 95\% przypadków zawsze trafi. [...] Powiem szczerze, że pierwszy raz po prostu mam do czynienia z osoba, która zna te ksiażki. Która rzeczywiście po prostu czytała i może coś polecić, a nie traktuje swojej pracy jako po prostu miejsca pracy, że trzeba przyjść, odsiedzieć, nie wiem, osiem godzin, czy tam dziewięć, czy dziesięć, jak się robi jeszcze jakieś dodatkowe rzeczy i wyjść do domu. Która rzeczywiście ta praca żyje.

Relacja głęboka charakteryzuje się z kolei kolektywizmem, nastawieniem na wspólnotę, grupę, zbiorowość. Obie strony relacji, i użytkownicy, i biblioteka, angażują w nią swoje zasoby i czerpią z niej korzyści. Uczestnicy badania opisywali ją słowami „współpraca”, „udział w bibliotece”, „praca, działanie na rzecz biblioteki”. Bardzo charakterystyczne było też, że gdy opowiadali o swoim wolontariacie lub o prowadzonych przez siebie w bibliotece działaniach, zaczynali mówić w pierwszej osobie liczby mnogiej - w tym „my” mieszczą się i użytkownicy, i bibliotekarze. Świadczy to, jak można zinterpretować, o głębokim zaangażowaniu.

Anna: I pamiętam jedna "Zimę w mieście”, na która po prostu codziennie przychodziłam do biblioteki. I pamiętam taki bardzo fajny element, że szyliśmy kurczaki. [...] To była tak zwana produkcja drobiu w bibliotece. No, była rewelacja. Wszystko zaczęło się od tego, że kiedyś tam siedzieliśmy i pani [...] chciała znaleźć jakiś fajny pomyst, żebyśmy tam przychodzili i naprawdę póżniej, jak na to wpadła... Miała mnóstwo jakichś takich różnych fajnych oczek dla zabawek, dla pluszaków. Ja przyniosłam, ponieważ mój dziadek byt 
krawcem, więc on ma dużo różnych skrawków materiałów, ja je przyniosłam [...]. I to był też taki czas, kiedy ja przyprowadzałam, raz na jakiś czas, bo ja przychodziłam tam codziennie, ale jednego dnia, jak moja koleżanka mogła przyjść, to ja zapraszałam, i jakby tam spędzałyśmy razem czas $i$ szyłyśmy kurczaki, tak? Przyprowadziłam takiego maluszka, [...], który miał takie dosyć trudne dzieciństwo, bo ja się też nim zajmowatam i jakby też się tam $z$ nim bawiłam. I potem go przyprowadziłam właśnie do biblioteki. No, więc też mój udziat w bibliotece był taki, że przyciagałam sporo nowych osób, nie?

Dariusz: Zorganizowaliśmy tutaj przedstawienie fajne dla dzieciaków. [...] No i w tym roku mamy nowa siłe robocza, że tak powiem [...] i będziemy też coś chcieli. Wiadomo, dzieciaki jeszcze maja szkołę na razie. Jak dzieci będa miały ten wolny czas, zorganizujemy [...]. [Pytanie]: I byt pan też na widowni na pewno. Dariusz: Na pewno, no, musiałem z racji całego tego wkładu pracy zobaczyć, jakie to owoce przyniesie.

Nie wartościując tych relacji, można by uporządkować je ze względu na rosnący poziom zaangażowania obu stron - od płytkiej do głębokiej. Można opisywać je w wymiarze tego, na jakim podmiocie koncentruje się relacja i przedstawić na skali pomiędzy indywidualizmem i kolektywizmem $^{5}$. Graficznie przedstawia to wykres 1.

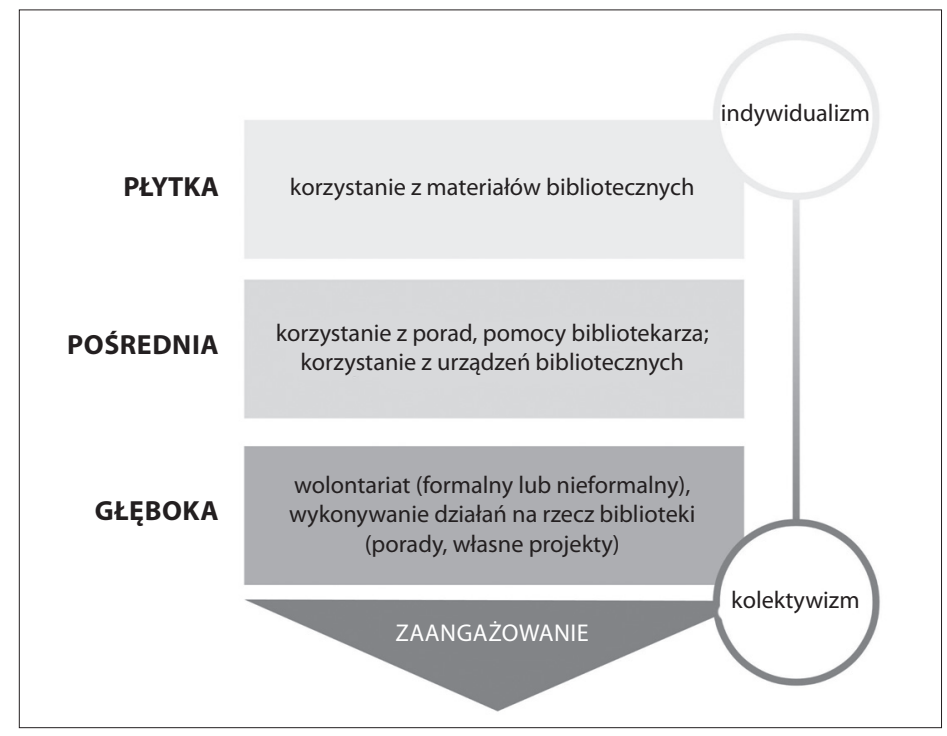

Wykres 1. Poziomy relacji z biblioteką

Źródło: oprac. własne 2018.

\footnotetext{
${ }^{5} \mathrm{O}$ znaczeniu tych wymiarów dla rzeczywistości funkcjonowania bibliotek wg teorii wymiarów kultury Geerta Hofstede pisali już wcześniej m.in. Bożena Jaskowska (2005, 2008), Marcin Pędich (2008, 2010, 2014) i Elżbieta Barbara Zybert (2004).
} 
O ile trudno byłoby umieścić w kwestionariuszu ankiety pytanie o postrzeganie relacji z biblioteka, można sprawdzić, na ile zarysowany powyżej teoretyczny koncept jej poziomów, oparty na zróżnicowaniu jakościowym działań podejmowanych w bibliotekach, jest spójny. W tym celu obliczono współczynnik $\alpha$ Cronbacha dla wyszczególnionych grup zmiennych z pytania kwestionariusza dotyczącego działań wykonywanych w bibliotekach publicznych w ciągu 12 miesięcy poprzedzających badanie. Wyniki przedstawia tabela 1.

Tabela 1

Współczynnik $\alpha$ Cronbacha dla poziomów relacji z biblioteką

\begin{tabular}{|c|c|c|}
\hline $\begin{array}{l}\text { Poziom } \\
\text { relacji }\end{array}$ & Przyporządkowane zmienne & $\begin{array}{c}\text { Współczynnik } \\
\alpha \text { Cronbacha - miara } \\
\text { spójności skali }\end{array}$ \\
\hline \multirow{9}{*}{$\begin{array}{c}\text { Relacja } \\
\text { na poziomie } \\
\text { płytkim }\end{array}$} & Pyt. 3.1. Wypożyczanie książek & \multirow{9}{*}{$\begin{array}{c}\alpha=0,578 \\
\text { po usunięciu } \\
\text { P3.1 i P3.11 } \\
\alpha=0,657\end{array}$} \\
\hline & Pyt. 3.2. Wypożyczanie audiobooków i ebooków & \\
\hline & Pyt. 3.3. Czytanie książek na miejscu & \\
\hline & Pyt. 3.4. Korzystanie z gazet i czasopism & \\
\hline & Pyt. 3.5. Korzystanie z innych materiałów & \\
\hline & Pyt. 3.6. Uczenie się indywidualne & \\
\hline & Pyt. 3.7. Uczenie się w grupie & \\
\hline & Pyt. 3.8. Praca naukowa lub zarobkowa & \\
\hline & Pyt. 3.11. Rozmawianie & \\
\hline \multirow{8}{*}{$\begin{array}{c}\text { Relacja } \\
\text { na poziomie } \\
\text { pośrednim }\end{array}$} & Pyt. 3.9. Udział w kursach & \multirow{8}{*}{$\alpha=0,739$} \\
\hline & Pyt. 3.10. Udział w wykładach, prelekcjach & \\
\hline & Pyt. 3.13. Uczestniczenie w spotkaniach autorskich & \\
\hline & Pyt. 3.14. Oglądanie wystaw & \\
\hline & Pyt. 3.15. Uczestniczenie w innych imprezach kulturalnych & \\
\hline & Pyt. 3.21. Korzystanie z komputerów i internetu & \\
\hline & Pyt. 3.22. Korzystanie z ksero, drukarek, skanerów & \\
\hline & Pyt. 3.23. Korzystanie z innych urządzeń & \\
\hline \multirow{6}{*}{$\begin{array}{c}\text { Relacja } \\
\text { na poziomie } \\
\text { głębokim }\end{array}$} & Pyt. 3.12. Spotykanie się ze znajomymi & \multirow{6}{*}{$\begin{array}{c}\alpha=0,593 \\
\text { po usunięciu P3.12 } \\
\alpha=0,615\end{array}$} \\
\hline & Pyt. 3.16. Zaangażowanie w akcje charytatywne & \\
\hline & Pyt. 3.17. Bycie wolontariuszem & \\
\hline & Pyt. 3.18. Spotykanie się z przedstawicielami samorządu & \\
\hline & Pyt. 3.19. Głosowanie w budżecie partycypacyjnym & \\
\hline & Pyt. 3.20. Realizowanie własnych projektów społecznych & \\
\hline
\end{tabular}

Źródło: oprac. własne. 
Wyniki wskazują na dość akceptowalny poziom spójności baterii pytań przyporządkowanych do trzech poziomów relacji ${ }^{6}$, choć jest on wciąż niższy niż $\alpha$ Cronbacha dla całego zestawu 21 zmiennych (po zredukowaniu P3.1 ze względu na odwrotną korelację $\alpha=0,832$ ). Próbując to zinterpretować, można by powiedzieć, że choć możemy wyróżnić poziomy relacji z bibliotekami na podstawie działań wykonywanych w tych instytucjach kultury, w perspektywie większej zbiorowości użytkowników różnice między nimi zacierają się niejako, a poziomy te wydają się przecinać w praktyce korzystania z usług bibliotecznych.

Aby lepiej zrozumieć kwestię poziomów relacji z biblioteka, zanalizowano, jakiego rodzaju czynniki mają znaczenie dla sposobów korzystania z bibliotek.

\section{CZYNNIKI MAJĄCE WPŁYW NA POZIOM RELACJI}

Uczestnicy badania charakteryzowali momenty, w czasie których korzystali z bibliotek mniej intensywnie lub wcale. Na podstawie danych można powiedzieć, że rozluźnienie relacji lub uniemożliwienie przeniesienia jej na kolejny poziom wynika z trzech czynników:

- małej dostępności czasu wolnego - korzystanie z bibliotek staje się wtedy którąś w kolejności czynnością wykonywaną przez daną osobę; jeśli istnieją więc inne czynniki niesprzyjające, relacja zostaje ograniczona,

- istnienia alternatywnych źródeł korzyści - jeżeli użytkownik posiada alternatywne źródła dostępu do książek, urządzeń, czy innych miejsc, w których może realizować własne projekty, a w dodatku jest to wygodniejsze i mniej kosztowne (także jeśli chodzi o wykorzystanie czasu, por. powyżej), może ograniczyć swoje korzystanie z bibliotek,

- brak odwzajemnienia zaangażowania - w przypadku, gdy użytkownik wykonuje krok inicjujący przejście na kolejny poziom relacji, a bibliotekarz nie odpowiada na to zaangażowaniem, osoba ta może się zniechęcić i zaniechać prób.

Przykładowe cytaty prezentujące tego rodzaju sytuacje zamieszczono w tabeli 2.

${ }^{6}$ Zazwyczaj przyjmuje się, że wartośc $\alpha$ Cronbacha powyżej 0,7 jest satysfakcjonującym wskaźnikiem spójności, minimalnie powinna być równa lub większa niż 0,6 . 
Czynniki mające wpływ na relację z biblioteką

\begin{tabular}{|c|c|}
\hline \multirow{2}{*}{$\begin{array}{l}\text { Mała dostępność } \\
\text { czasu wolnego }\end{array}$} & $\begin{array}{l}\text { Emil: To troszkę zależy od tego, jak się moje życie układa. W momentach, kiedy } \\
\text { jestem luźniejszy, jak teraz, kiedy formalnie rzecz biorac, nie pracuję, chodze } \\
\text { czéściej. No, jak jestem spẹtany praca, to jest to trochę rzadziej. No, bo wtedy } \\
\text { nie jestem w stanie tak dużo czytać, jak bym chciat, mógt, jak by się dało. Więc } \\
\text { to jest zmienne. }\end{array}$ \\
\hline & $\begin{array}{l}\text { Grzegorz: To potem nie, ja raczej nie chodzitem do bibliotek. Nawet i czasu } \\
\text { nie miałem i takiego zainteresowania nie byto jakiegoś. Tylko tam praca, [nie- } \\
\text { pełnosprawny] ojciec. [...] I potem poszedtem do państwowej pracy. To już, } \\
\text { wie pani, zupełnie inne horyzonty, bo jest osiem godzin pracy i czas wolny. No, } \\
\text { więc przychodzitem i co? Patrzeć się w telewizor? }\end{array}$ \\
\hline $\begin{array}{l}\text { Alternatywne } \\
\text { źródła korzyści }\end{array}$ & $\begin{array}{l}\text { Joanna: A, bo to jeszcze sie zwiazało z tym, że miałam biblioteke w domu, } \\
\text { miałam większa. I to taká przyzwoita miałam. I biblioteka mi się wyprowadzi- } \\
\text { ta. [Śmiech]. No, a pózniej korzystałam, nawet, jak mi sie wyprowadzita, to } \\
\text { korzystałam z tej biblioteki. To była taka przyzwoita biblioteka, była. No, a co } \\
\text { mam w domu? Coś tam mam, nie powiem, że nic nie mam, bo kiedyś tam się } \\
\text { kupowało, coś tam zawsze. }\end{array}$ \\
\hline \multirow[b]{2}{*}{$\begin{array}{l}\text { Brak odwzajemnienia } \\
\text { zaangażowania }\end{array}$} & $\begin{array}{l}\text { Anna: Znaczy nie czuję tam takiej więzi, że chce się przyjść, coś porobić i tak } \\
\text { dalej. Nawet miałam pomyst na jakieś fajne warsztaty, żeby przeprowadzić } \\
\text { i nawet chciałam, rozmawiałam z jedna z pań bibliotekarek, ale w końcu nie } \\
\text { udałam sie do kierowniczki, żeby z nia porozmawiać. Jakoś nie przyciagaja } \\
\text { mnie w niczym. }\end{array}$ \\
\hline & $\begin{array}{l}\text { Henryk: Beletrystyki bardzo mało czytam. Nawet kilka razy pytałem w bi- } \\
\text { bliotece, czy pani by mi coś poleciła, ale jakoś tak ta odpowiedź nie spotkała się } \\
\text { z żadnym echem, że aż byłem zdziwiony. [...] Idealna biblioteka to być może } \\
\text { więcej takich sugestii od samych pracowników biblioteki, takich pewnych... } \\
\text { Nie mówię, że tego nie ma, ale kilka razy, szczególnie w zakresie beletrystyki, } \\
\text { spotkatem się z takim chłodnym, przynajmniej w dwóch bibliotekach, z takim } \\
\text { chłodnym stanowiskiem, czy przyjęciem, że trochę bytem zdziwiony. Może } \\
\text { akurat tacy pracownicy się trafili. }\end{array}$ \\
\hline
\end{tabular}

Źródło: oprac. własne.

Czynniki odwrotne, a więc większa dostępność czasu wolnego, ograniczenie alternatywnych źródeł oraz odwzajemnienie zaangażowania byłyby więc odpowiedzialne za pogłębianie się relacji. Znajduje to potwierdzenie w danych. Joanna opowiadała, że zaczęła więcej czytać, a przez to korzystać z biblioteki, kiedy przeszła na emeryturę, a książki, które miała dostępne w domu, już jej nie wystarczały. Dla tej samej osoby czynnikiem decydującym był fakt, że nie miała w domu dostępu do sieci internetowej, a odczuwała silną potrzebę, aby z niej skorzystać.

Nie, ja przyszłam, bo, wie pani, nie miałam internetu. To znaczy internet tam jakiś miałam, ale musiałam skorzystać z poczty elektronicznej. I przyszłam $i$ skorzystałam $z$ tej poczty. I właściwie to pierwszy raz przyszłam... A nawet karty nie miałam, bo to trzeba było mieć karte nawet, żeby z poczty, $z$ tej, żeby z internetu skorzystać, z komputera skorzystać. I pani wyrobiła mi tutaj tę kartę. I później myśle - dlaczego ja nie korzystam? A jeszcze sympatyczna osoba jakaś taka. Myśle - dlaczego ja z tego nie korzystam? 
Z kolei w wypowiedzi Henryka można znaleźć opis sytuacji, w której czytelnik i bibliotekarz zainteresowali się nawzajem swoimi pasjami.

I jakieś takie polecanie sobie ksiażek, czy jakichś spotkań, czy wyjazdów. [...] Ja zainspirowałem, ale nie to, ̇̇e chciałem zainspirować, ale jakoś $w$ toku dyskusji wyszło, że coś jest takiego, co ta osoba szuka, a o czym nie wiedziała. A z kolei ja od tej osoby też się czegoś dowiedziałem innego i w ten sposób jest takie wtaśnie forum wymiany myśli.

Dwie pierwsze ze wskazanych przyczyn można zoperacjonalizować do trzech zmiennych występujących w badaniu ilościowym. W przypadku dostępności czasu wolnego byłaby to częstotliwość korzystania $\mathrm{z}$ bibliotek, a jeśli chodzi o alternatywne źródła korzyści - korzystanie z innych instytucji kultury oraz korzystanie z mediów innych niż książki i prasa. Odwzajemnienie zaangażowania jest tak subiektywnym aspektem, że trudno jest znaleźć zmienna, która mogłaby mu odpowiadać w analizie ilościowej.

Na podstawie wyników testów chi-kwadrat zaobserwowano następujące zależności pomiędzy zmiennymi:

- częstotliwość chodzenia do bibliotek ma związek z 15 zmiennymi.

- korzystanie z innych instytucji kultury ma związek ze wszystkimi zmiennymi (22, oprócz wypożyczania książek).

- korzystanie z innych mediów ma związek z 2 zmiennymi (wyłącznie z wypożyczaniem audiobooków i e-booków oraz głosowaniem w budżecie partycypacyjnym).

Dla par zmiennych, dla których wystąpił istotny statystycznie związek, przeprowadzono następnie analizę ze zmiennymi kontrolnymi. Związek pomiędzy zmiennymi został potwierdzony w przypadku korzystania $\mathrm{z}$ innych instytucji kultury oraz trzech zmiennych dotyczących korzystania z bibliotek, a jego siła jest następująca:

- uczestniczenie w spotkaniach autorskich ( $\varrho S=0,196 ; \mathrm{p}<0,001)$,

- uczestniczenie w innych imprezach kulturalnych ( $\mathrm{QS}=0,234 ; \mathrm{p}<0,001)$,

- spotykanie się z przedstawicielami samorządu ( $\varrho S=0,196 ; \mathrm{p}<0,001)$.

Ponieważ jednak wydaje się, że to zmienne kontrolne mają większe znaczenie dla zróżnicowania odpowiedzi na pytania dotyczące korzystania z bibliotek, dla par tych zmiennych przeprowadzono testy chi-kwadrat. Wyniki można by podsumować następująco:

- osoby młodsze są bardziej skłonne do wykonywania w bibliotekach następujących działań: czytanie książek na miejscu, uczenie się indywidualnie i w grupie, prowadzenie pracy naukowej i zarobkowej, korzystanie z komputerów, internetu i innych urządzeń biurowych. Natomiast im osoba starsza, tym częściej deklaruje czytanie książek i prasy, udział w kursach, spotykanie się ze znajomymi, uczestni- 
czenie w spotkaniach autorskich, oglądanie wystaw, uczestniczenie $\mathrm{w}$ innych imprezach kulturalnych, zaangażowanie $\mathrm{w}$ akcje charytatywne, głosowanie $\mathrm{w}$ budżecie partycypacyjnym oraz realizowanie własnych projektów społecznych.

- osoby o gorszej sytuacji finansowej są bardziej skłonne do czytania książek na miejscu i korzystania z gazet i czasopism, a także uczestniczenia w spotkaniach autorskich i korzystania z komputerów, Internetu i innych urządzeń biurowych. Osoby o lepszej sytuacji finansowej są bardziej skłonne do wypożyczania książek i głosowania na bibliotekę w budżecie partycypacyjnym.

- osoby zamieszkujące w mniejszych gospodarstwach domowych są bardziej skłonne do korzystania z gazet i czasopism i rozmawiania z bibliotekarzami lub innymi użytkownikami. Osoby zamieszkujące w większych gospodarstwach domowych są bardziej skłonne do wypożyczania książek, wypożyczania audiobooków i ebooków i korzystania z innych materiałów (filmy, płyty, gry).

- osoby z większych miejscowości są bardziej skłonne do wypożyczania książek w każdej formie i do korzystania z innych materiałów (filmy, płyty, gry).

- $\mathrm{w}$ pozostałych przypadkach nie ma związku między zmiennymi poziom istotności wynosi powyżej 0,05. Związek pomiędzy wszystkimi zmiennymi branymi pod uwagę jest nikły lub słaby.

Podsumowując, w czasie analizy ilościowej sprawdzono, czy zmienne takie, jak dostępność czasu wolnego i korzystanie z innych niż biblioteki instytucji kultury oraz mediów innych niż książka i prasa różnicują próbę pod względem korzystania z bibliotek. Początkowo wydawało się, że duże znaczenie ma szczególnie częstotliwość korzystania z bibliotek, natomiast $\mathrm{w}$ trakcie analizy ze zmiennymi kontrolnymi związek ten okazał się pozorny. Podobnie $\mathrm{w}$ przypadku korzystania $\mathrm{z}$ innych mediów był on nieistotny. Korzystanie $z$ innych instytucji kultury miało znaczenie dla niektórych zmiennych, ale związek ten miał inny kierunek niż sugerowały to wypowiedzi rozmówców w czasie wywiadów. Korzystanie z innych niż biblioteki instytucji sprzyjało wykonywaniu w bibliotece takich działań, jak: uczestniczenie w spotkaniach autorskich, uczestniczenie $\mathrm{w}$ innych imprezach kulturalnych i spotykanie się z przedstawicielami samorządu. Przykład ten pokazuje, że:

- wywiady jakościowe mogą być punktem wyjścia do interesujących analiz materiału ilościowego,

- odrzucenie hipotez zarysowanych w ten sposób nie świadczy o błędnej interpretacji rzeczywistości społecznej przez badanych, a raczej o odmienności doświadczeń na poziomie mikro i zależności zachodzących między zmiennymi na poziomie makro. 
Opisana w niniejszym artykule koncepcja relacji z biblioteką została wypracowana $w$ ramach badania wpływu społecznego bibliotek i łączy się z nim w sposób bezpośredni. Na podstawie przeprowadzonych badań wypracowano teorię, że wpływ społeczny bibliotek publicznych, polegający na budowie kapitału kulturowego i społecznego, jest wynikiem tejże relacji. Łączenie jakościowych i ilościowych danych oraz metod badawczych wydaje się szczególnie istotne dla badania wpływu bibliotek.

\section{ROLA TRIANGULACJI W BADANIACH WPŁYWU SPOŁECZNEGO BIBLIOTEK}

Debata na temat triangulacji $w$ badaniach społecznych rozpoczęła się za sprawą konceptualizacji tego pojęcia dokonanej w latach 60. XX w. przez Normana Denzina. Jednakże sama koncepcja łączenia różnych metod i danych w celu zapewnienia jakości badań ma dłuższą tradycję (Flick, 2011, s. 76-81). Triangulację szeroko zdefiniował Uwe Flick: „Triangulacja zakłada prowadzenie badań przez kilku badaczy, przyjmujących różne podejścia do badanego zagadnienia lub - szerzej - stosujących różne sposoby odpowiadania na pytania badawcze. Te podejścia mogą być zakorzenione $\mathrm{w}$ różnych metodach i/lub perspektywach teoretycznych. Jedne i drugie są lub powinny być wzajemnie połączone. Oprócz tego triangulacją nazywamy łączenie różnych rodzajów danych osadzonych w różnych perspektywach teoretycznych. O ile to możliwe, perspektywy te powinno się stosować w sposób równoprawny i jednakowo konsekwentny. Triangulacja (różnych metod lub rodzajów danych) ma w założeniu doprowadzić do uzyskania istotnej nadwyżki wiedzy. Przykładowo, triangulacja powinna przyczyniać się do wytworzenia wiedzy na kilku poziomach, dzięki czemu na każdym z nich możliwe staje się wyjście poza wiedzę dostarczoną przez jedno podejście, co pozwala podnieść jakość badań" (Flick, 2011, s. 81).

W definicji tej widać, że triangulacja może mieć różne rodzaje. Osobnym zagadnieniem jest triangulacja metod jakościowych i ilościowych, często błędnie utożsamiana z samym pojęciem triangulacji. Koncepcja ta nie jest jednak niekontrowersyjna i wpisuje się w dyskusję szerszą i tak ostra, że na gruncie amerykańskim została nazwana „wojną paradygmatów”, dotyczącą odmienności metodologicznych, teoretycznych i praktycznych metod ilościowych i jakościowych. O ile w perspektywie epistemologicznej badacze-metodolodzy podkreślają fundamentalną niewspółmierność tych podejść, o tyle w ujęciu technicznym różnice te nie są uważane za nieprzekraczalne. Kolejna kontrowersja polega na tym, że włączenie metod ilościowych implikować ma kwestionowanie samodzielności i wartości badań opartych na metodach jakościowych jako wyizolowanego podejścia (Flick, 2011, s. 154-157). „Mimo to - zaznacza Flick - refleksyjne korzystanie z podejść ilościowych może przyczynić się do podniesienia 
jakości badań opartych w większości lub w części na metodach jakościowych" (Flick, 2011, s. 154), czego wyrazem może być rosnąca popularność metodologii badań mieszanych.

Badania mieszane określane są $\mathrm{w}$ różnorodny sposób, np. badania integrujące, syntetyczne, polimetodyczne. Powstanie koncepcji tych badań przypisuje się Donaldowi T. Campbellowi i Donaldowi W. Fiske (Campbell \& Fiske, 1959). Popularność tej metodologii zdaje się wzrastać (Johnson \& Onwuegbuzie, 2004; Tashakkori \& Creswell, 2007), na co wskazuje również zainteresowanie nimi wśród teoretyków i badaczy z zakresu bibliologii i informatologii (np. Cisek, 2010, a także: Jasiewicz, 2017, 2018). Jako ich zaletę uznać można poszerzenie perspektywy badawczej oraz możliwość zastosowania jednego ujęcia, aby lepiej zrozumieć i wyjaśniać drugie. Wyzwaniem jest natomiast pozyskiwanie obszernego zbioru danych, czasochłonność analizy oraz konieczność znajomości metodologii obu podejść badawczych (Creswell, 2013, s. 39-41, 219-232).

W normie ISO 16439:2014 Information and documentation - Methods and procedures for assessing the impact of libraries, pierwszego i jedynego do tej pory dokumentu normalizującego, odnoszącego się wprost do badań wpływu bibliotek, postuluje się korzystanie z metod mieszanych. Można znaleźć $\mathrm{w}$ niej stwierdzenie, że użycie kilku metod, gromadzenie i analizowanie danych różnych typów i pochodzenia, może dostarczyć bogatszego, bardziej zniuansowanego zestawu wniosków, które moga prowadzić do lepszego wglądu, zrozumienia i identyfikacji wpływu biblioteki i zwiększyć przeświadczenie o prawidłowości konkluzji ustalonych w czasie badania ewaluacyjnego. W praktyce bibliotecznej metodą łączenia może być zastosowanie procesu iteracyjnego, w którym wyniki jednego badania są śledzone przez kolejne, w celu lepszego zrozumienia problemów i samego wpływu (ISO, 2014, pp. 22-23).

Wśród zalet łączenia metod wymienia się:

- stosowanie różnych metod może potwierdzić ustalenia,

- dane z różnych źródeł nadają kontekst i ułatwiają zrozumienie,

- narracje użytkowników mogą stanowić uzupełnienie danych ilościowych (ISO, 2014, p. 57).

Norma punktuje również wady tego rozwiązania metodologicznego:

- zestawy danych mogą nie być kompatybilne względem siebie,

- analiza danych może wskazywać na korelację, ale niekoniecznie związek przyczynowy,

- wymagana jest znajomość różnorodnych narzędzi analizy danych,

- mogą być wymagane grupy kontrolne,

- do uzyskania danych spoza biblioteki niezbędna jest współpraca, a w przypadku wykorzystania danych dotyczących indywidualnych użytkowników może być potrzebne pozwolenie na zebranie zanonimizowanych danych (ISO, 2014, p. 57). 


\section{PODSUMOWANIE}

Koncepcja relacji z bibliotekami została wypracowana na podstawie danych jakościowych. W oparciu o ich wypowiedzi udało się zrekonstruować, jak rozumiana może być relacja powstająca między użytkownikiem a bibliotekarzami i innymi użytkownikami, na jakich poziomach przebiega i co wpływa na jej istnienie oraz na skalę zaangażowania w nią obu stron. Co ważne - relacja ta występowała w przypadku wszystkich badanych osób, bez względu na to, czy byli stałymi, czy okazjonalnymi użytkownikami. W kolejnym kroku należałoby natomiast $\mathrm{z}$ pewnością zbadać pod tym kątem nieużytkowników bibliotek, gdyż dotychczasowe analizy sugeruja że istnieją różnice pomiędzy użytkownikami i nieużytkownikami bibliotek, jeżeli chodzi na przykład o korzystanie z mediów (Bhatt, 2010) oraz w kontekście szeregu charakterystyk społeczno-ekonomicznych (Sin i Kim, 2008).

Wydaje się trudne, jeżeli nie niemożliwe, potwierdzenie lub sfalsyfikowanie samego konceptu relacji z bibliotekami na podstawie zebranych danych ilościowych, natomiast pozwoliły one określić, na ile spójna jest koncepcja poziomów relacji i czy wpływ zmiennych, widoczny z poziomu jednostki, utrzymuje się w przypadku analizowania większej zbiorowości. $W$ tym przypadku można wnioskować, że znaczenie zmiennych związanych z korzystaniem z kultury „zaciera się”, a większą rolę mają zmienne społeczno-demograficzne.

\section{BIBLIOGRAFIA}

Bhatt, R. (2010). The impact of public library use on reading, television, and academic outcomes. Journal of Urban Economics, 68(2), pp. 148-166.

Campbell, Donald T.; Fiske, Donald W. (1959). Convergent and discriminant alidation by the multitrait-multimethod matrix. Psychological Bulletin, vol. 56, no. 2, pp. 81-105.

Charmaz, Kathy (2013). Teoria ugruntowana: praktyczny przewodnik po analizie jakościowej. Warszawa: Wydaw. Naukowe PWN.

Cisek, Sabina (2010). Metodologia mieszana w badaniach nauki o informacji i bibliotekoznawstwa. W: M. Kocójowa (red.), Biblioteki, informacja, ksiażka: interdyscyplinarne badania i praktyka w 21. wieku. Kraków: IINiB UJ, s. 88-94.

Creswell, John W. (2013). Projektowanie badań naukowych: metody jakościowe, ilościowe i mieszane. Kraków: Wydaw. Uniwersytetu Jagiellońskiego.

Flick, Uwe (2011). Jakość w badaniach jakościowych. Warszawa: Państwowe Wydaw. Naukowe.

Gmiterek, Grzegorz (2012). Biblioteka w środowisku społecznościowego Internetu: biblioteka 2.0. Warszawa: Wydaw. SBP.

Hvenegaard Rasmussen, Casper (2016). The participatory public library: the Nordic experience, New Library World, vol. 117, iss, 9/10, pp. 546-556.

Hryniewicz, Konrad (2016). Wyciskanie sensu z alfy cronbacha - analiza rzetelności, [online]. [dostęp: 09.04.2018]. Dostępny w WWW: <http://nauka.metodolog.pl/wyciskaniesensu-z-alfy-cronbacha-analiza-rzetelnosci/>. 
ISO (2014). ISO 16439:2014 Information and documentation -- Methods and procedures for assessing the impact of libraries.

Jasiewicz, Justyna (2017). Obszary, problemy i metody badawcze Library and Information Science. Część I. Przegląd Biblioteczny, R. 85, z. 4, s. 496-512.

Jasiewicz, Justyna (2018). Obszary, problemy i metody badawcze Library and Information Science. Część II. Przegląd Biblioteczny, R. 86, z. 1, s. 16-32.

Jaskowska, Bożena (2005). Biblioteka w kulturze - kultura w bibliotece: procesy informacyjno-biblioteczne na tle polskiej kultury narodowej. W: H. Ganińska (red.), Biblioteki naukowe w kulturze i cywilizacji: działania i codzienność. Poznań: Biblioteka Główna Politechniki, s. 30-41.

Jaskowska, Bożena (2008). Jak badać kulturę organizacyjną w bibliotece akademickiej? W: H. Brzezińska-Stec (red.), Kultura organizacyjna w. Białystok: Wydaw. Uniwersytetu w Białymstoku, s. 25-42.

Jaskowska, Bożena i Dudczak, Adam (2007). Library 2.0 - rewolucja i przełom, czy kolejny etap rozwoju współczesnego bibliotekarstwa? Przegląd Biblioteczny, z. 3, s. 354-365.

Johnson, Catherine. A. (2012). How do public libraries create social capital?: an analysis of interactions between library staff and patrons. Library and Information Science Research, vol. 34, no. 1, pp. 52-62.

Johnson, Catherine. A.; Griffis, Matthew. R. (2014). The effect of public library use on the social capital of rural communities. Journal of Librarianship and Information Science, vol. 46, no. 3, pp. 179-190.

Johnson, R. Burke; Onwuegbuzie, Anthony. J. (2004). Mixed Methods Research: A Research Paradigm Whose Time Has Come. Educational Researcher, vol. 33, no. 7, pp. 14-26.

Lissowski, Grzegorz; Haman, Jacek; Jasiński, Mikołaj (2011). Podstawy statystyki dla socjologów. T. 2, Zależności statystyczne. Warszawa: Wydaw. Naukowe Scholar.

Pędich, Marcin (2008). Biblioteka w pięciu wymiarach - budownictwo biblioteczne w kontekście wymiarów kultury według Geerta Hofstedego. W: Kultura organizacyjna w bibliotece pod red. Haliny Brzezińskiej-Stec. Białystok: Wydaw. Uniwersytetu w Białymstoku, s. 427-439.

Pędich, Marcin (2010). Kontekst kulturowy a motywowanie pracowników bibliotek. W oparciu o teorię wymiarów kultury Geerta Hofstedego. W: Marketing wewnętrzny i zarządzanie zasobami ludzkimi w bibliotece pod red. Haliny Brzezińskiej-Stec i Jolanty Kudrawiec. Białystok: Wydaw. Uniwersytetu w Białymstoku, s. 180-190.

Pędich, Marcin (2014). Biblioteka w świetle teorii wymiarów kultury. Zarządzanie Bibliote$k a$, nr 1 (6), s. 33-42.

Relacja [online] (b.d.). [dostęp: 09.04.2018]. Dostępny w WWW: <https://sjp.pwn.pl/szukaj/ relacja.html>.

Tashakkori, Abbas; Creswell, John W. (2007). Editorial: The New Era of Mixed Methods. Journal of Mixed Methods Research, vol. 1, no. 1, pp. 3-7.

Test zgodności chi-kwadrat. [online] (2016). [dostęp: 09.04.2018]. Dostępny w WWW: <https:// mfiles.pl/pl/index.php/Test_zgodności_chi-kwadrat>.

Turner, Jonathan. H. (2012). Struktura teorii socjologicznej. Warszawa: Państwowe Wydaw. Naukowe.

Zybert. Elżbieta Barbara (2004). Kultura organizacyjna w bibliotekach. Warszawa: Wydaw. SBP. 


\section{Aneks 1 - Charakterystyka uczestników badania jakościowego}

Charakterystyka uczestników badania jakościowego

\begin{tabular}{|c|c|}
\hline $\begin{array}{l}\text { Imię } \\
\text { (zmienione) }\end{array}$ & Opis uczestnika badania \\
\hline Anna & $\begin{array}{l}\text { Kobieta, } 28 \text { lat. Wykształcenie wyższe, studiowała bibliotekoznawstwo } \\
\text { oraz inne kierunki. Obecnie pracuje w sektorze publicznym. Jej praca nie } \\
\text { jest związana z bibliotekami i jej relacja z nimi rozluźniła się, choć nadal } \\
\text { ma do nich wielki sentyment. }\end{array}$ \\
\hline Barbara & $\begin{array}{l}\text { Kobieta, } 68 \text { lat. Wykształcenie zawodowe. Pracowała na stanowiskach } \\
\text { administracyjnych w różnych przedsiębiorstwach i instytucjach. Obec- } \\
\text { nie jest na emeryturze, co sprawia, że z jednej strony ma dużo wolnego } \\
\text { czasu, ale także obniżył się jej status ekonomiczny. Czytanie jest dla niej } \\
\text { podstawową rozrywką. }\end{array}$ \\
\hline Celina & $\begin{array}{l}\text { Kobieta, } 24 \text { lata. Wykształcenie wyższe. Studiuje kierunek techniczny. } \\
\text { Od wielu lat jest wolontariuszką w jednej z warszawskich bibliotek. }\end{array}$ \\
\hline Dariusz & $\begin{array}{l}\text { Mężczyzna, } 67 \text { lat. Wykształcenie zawodowe. Jest zarejestrowany jako } \\
\text { osoba bezrobotna, pracuje dorywczo fizycznie. Zbliża się do emerytury. } \\
\text { Niedawno przeprowadził się w nowe miejsce i tam zaczął bardzo inten- } \\
\text { sywnie korzystać z biblioteki. }\end{array}$ \\
\hline Emil & $\begin{array}{l}\text { Mężczyzna, } 43 \text { lata. Wykształcenie wyższe. Przedsiębiorca. Jego praca } \\
\text { ma charakter mało uregulowany, w związku z czym w okresach, gdy ma } \\
\text { więcej wolnego czasu, częściej korzysta z bibliotek. }\end{array}$ \\
\hline Felicja & $\begin{array}{l}\text { Kobieta, } 23 \text { lata. Wykształcenie wyższe. Pracuje w administracji, a jed- } \\
\text { nocześnie studiuje w trybie niestacjonarnym. Od czasu, gdy przyjechała } \\
\text { do Warszawy, korzystała z bibliotek w różnych dzielnicach, a także z Bi- } \\
\text { blioteki Uniwersyteckiej w Warszawie. }\end{array}$ \\
\hline Grzegorz & $\begin{array}{l}\text { Mężczyzna, } 67 \text { lat. Wykształcenie wyższe. Pracownik administracji. Wy- } \\
\text { kształcenie zdobył około piętnaście lat temu a biblioteki oraz wsparcie, } \\
\text { jakie w nich uzyskiwał, były ważnym elementem tego procesu. }\end{array}$ \\
\hline Henryk & $\begin{array}{l}\text { Mężczyzna, } 43 \text { lata. Wykształcenie wyższe. Pracował w różnych przed- } \\
\text { siębiorstwach, a obecnie prowadzi własną działalność. Kładzie duży na- } \\
\text { cisk na rozwój osobisty za pośrednictwem lektury, którą czerpie m.in. } \\
\text { z bibliotek publicznych. }\end{array}$ \\
\hline Ireneusz & $\begin{array}{l}\text { Mężczyzna, } 44 \text { lata. Wykształcenie wyższe. Artysta. Zaczął interesować } \\
\text { się literaturą późno, a obecnie lektury bywają dla niego źródłem inspira- } \\
\text { cji, ale w większości - rozrywki. }\end{array}$ \\
\hline Joanna & $\begin{array}{l}\text { Kobieta, } 64 \text { lata. Wykształcenie średnie techniczne. Obecnie na emerytu- } \\
\text { rze. Korzysta z biblioteki od trzech lat. }\end{array}$ \\
\hline Karolina & $\begin{array}{l}\text { Kobieta, } 37 \text { lat. Wykształcenie wyższe. Pracuje w sektorze prywatnym } \\
\text { jako specjalistka. Jest także młodą mamą, w związku z czym ma niewiele } \\
\text { czasu wolnego. Czyta jednak bardzo dużo. }\end{array}$ \\
\hline
\end{tabular}

Źródło: oprac. własne. Imiona rozmówców zostały zmienione. 


\section{Aneks 2 - Kwestionariusz ankiety}

1. Jak często w ciągu ostatnich 12 miesięcy korzystała Pani / korzystał Pan z bibliotek publicznych?

o częściej niż raz w tygodniu

o kilka razy w miesiącu

o raz na miesiąc

o kilka razy w roku

o rzadziej niż raz na rok

2. Z jakich innych bibliotek korzystała Pani / korzystał Pan w ciągu ostatnich 12 miesięcy? Odp.

3. Czy w ciągu ostatnich 12 miesięcy podejmowała Pani / podejmował Pan następujące działania w bibliotekach?

Wypożyczanie książek

tak / nie

Wypożyczanie audiobooków lub ebooków

tak / nie

Czytanie książek na miejscu

tak / nie

Korzystanie z gazet i czasopism

tak / nie

Wypożyczanie i korzystanie z innych materiałów (filmy, płyty, gry)

tak / nie

Uczenie się indywidualne, w samotności

tak / nie

Uczenie się w grupie

tak / nie

Praca naukowa lub inna praca zarobkowa

tak / nie

Udział w kursach,

tak / nie

jakich?

Udział w wykładach, prelekcjach

tak / nie

Rozmawianie z bibliotekarzami i z innymi użytkownikami

tak / nie

Spotykanie się ze znajomymi

tak / nie

Uczestniczenie w spotkaniach autorskich

tak/nie

Oglądanie wystaw

tak / nie

Uczestniczenie w innych imprezach kulturalnych,

tak / nie

jakich?

Zaangażowanie w akcje charytatywne

tak / nie

Bycie wolontariuszem w bibliotece

tak / nie

Spotykanie się z przedstawicielami samorządu

tak/nie

Głosowanie w budżecie partycypacyjnym

tak / nie

Realizowanie własnych projektów społecznych,

tak / nie

jakich?

Korzystanie z komputerów i internetu

tak/nie

Korzystanie z ksero, drukarek, skanerów

tak/nie

Korzystanie z innych urządzeń,

tak / nie

jakich? 
4. Biorąc pod uwagę korzystanie przez Panią / Pana z bibliotek publicznych w ciągu ostatnich 12 miesięcy, na ile zgadza się lub nie zgadza się Pani / Pan, że biblioteki publiczne zaspokoiły Pani / Pana potrzeby i oczekiwania w wymienionych poniżej obszarach.

\begin{tabular}{|c|c|c|c|c|c|c|c|}
\hline & 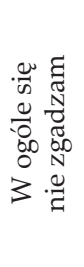 &  & 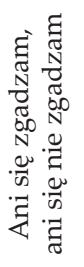 & 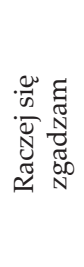 & 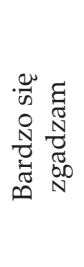 & 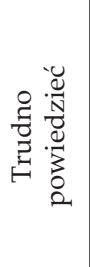 & 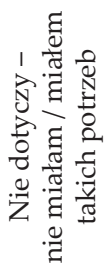 \\
\hline $\begin{array}{l}\text { Znalazłam / znalazłem interesującą mnie } \\
\text { informację }\end{array}$ & & & & & & & \\
\hline Pogłębiłam / pogłębiłem swoją wiedzę & & & & & & & \\
\hline $\begin{array}{l}\text { Miałam / miałem możliwość skorzystania } \\
\text { z materiałów nigdzie indziej niedostępnych }\end{array}$ & & & & & & & \\
\hline $\begin{array}{l}\text { Miałam / miałem możliwość skorzystania } \\
\text { z materiałów, na których zakup nie mogła- } \\
\text { bym / nie mógłbym inaczej sobie pozwolić }\end{array}$ & & & & & & & \\
\hline $\begin{array}{l}\text { Odpoczęłam / odpocząłem, odstresowałam } \\
\text { się / odstresowałem się }\end{array}$ & & & & & & & \\
\hline $\begin{array}{l}\text { Zapewniło mi to rozrywkę, relaks, } \\
\text { przyjemność }\end{array}$ & & & & & & & \\
\hline $\begin{array}{l}\text { Osiągnęłam / osiagnąłem lepsze wyniki } \\
\text { w nauce lub pracy }\end{array}$ & & & & & & & \\
\hline Zdobyłam / zdobyłem nowe umiejętności & & & & & & & \\
\hline $\begin{array}{l}\text { Wymieniłam / wymieniłem doświadczenia } \\
\text { z innymi ludźmi }\end{array}$ & & & & & & & \\
\hline Zawarłam / zawarłem nowe znajomości & & & & & & & \\
\hline $\begin{array}{l}\text { Miałam / miałem możliwość udziału } \\
\text { w wydarzeniach kulturalnych, na które } \\
\text { nie mogłabym / nie mógłby inaczej sobie } \\
\text { pozwolić }\end{array}$ & & & & & & & \\
\hline $\begin{array}{l}\text { Miałam / miałem możliwość udziału } \\
\text { w życiu społeczności lokalnej }\end{array}$ & & & & & & & \\
\hline $\begin{array}{l}\text { Zrobiłam / zrobiłem coś pożytecznego dla } \\
\text { społeczeństwa }\end{array}$ & & & & & & & \\
\hline $\begin{array}{l}\text { Miałam / miałem możliwość korzystania } \\
\text { z urządzeń, na których kupno nie mogła- } \\
\text { bym / nie mógłbym sobie inaczej pozwolić }\end{array}$ & & & & & & & \\
\hline $\begin{array}{l}\text { Miałam / miałem możliwość korzystania } \\
\text { z urządzeń nigdzie indziej niedostępnych }\end{array}$ & & & & & & & \\
\hline
\end{tabular}


M1. Płeć

o kobieta

o mężczyzna

M2. Rok urodzenia

Odp.

M3. Czy w ciągu ostatnich trzech miesięcy była Pani / był Pan:

$\mathrm{w}$ kinie

tak / nie

w domu kultury

tak/nie

$\mathrm{w}$ muzeum lub galerii

tak/nie

$\mathrm{w}$ teatrze lub filharmonii

tak / nie

na koncercie muzycznym

tak/ nie

na festiwalu artystycznym lub kulturalnym

tak / nie

na konferencji, wykładzie naukowym

tak/nie

M4. Ile czasu (minut lub godzin) poświęciła Pani w zeszłym tygodniu na (w dowolnej formie):

czytanie książek

czytanie gazet i czasopism

oglądanie telewizji

słuchanie radia

korzystanie $\mathrm{z}$ internetu

M5. Jak ocenia Pani / Pan swoją obecną sytuację finansową?

o mogę pozwolić sobie na kupno wszystkiego, na co mam ochotę, a niespodziewane wydatki nie są dla mnie problemem

o mogę pozwolić sobie na kupno wszystkiego, co jest mi potrzebne, ale na niespodziewane wydatki muszę odkładać

o wystarcza mi pieniędzy na opłacenie rachunków i najpotrzebniejsze rzeczy

o z trudem wystarcza mi na podstawowe potrzeby

M6. Ile osób liczy obecnie Pani / Pana gospodarstwo domowe (łącznie z niepełnoletnimi i pełnoletnimi dziećmi)?

Odp.

Artykut w wersji poprawionej wpłyną do Redakcji 15 października 2018 r. 


\section{MAGDALENA PAUL}

Faculty of Journalism, Information and Book Studies

University of Warsaw

e-mail: magdaa.paul@gmail.com

\section{USING LIBRARIES AS A FORM OF RELATIONSHIP - THE ANALYSIS OF A THEORETICAL CONCEPT WITH THE TRIANGULATION OF RESEARCH METHODS}

KEYWORDS: Librarians. Public libraries. Research methods. Triangulation. Library users. Social impact of public libraries.

ABSTRACT: Thesis / Objective - The article is an in-depth reflection on the use of triangulation based on the analysis of the social impact of public libraries in mazowieckie region. Research methods - The qualitative part of the research was done following the procedures of constructivist grounded theory and data was collected with IDI. The quantitative part was performed as random sample survey. Results - The use of libraries can be described as the relationship connecting librarians and library users on various, interconnecting levels. Taking into consideration the opinion of the library users the most important elements of this relationship are the amount of free time available, alternative sources of benefits and reciprocal involvement. If a larger community is involved, the methods and frequency of library use become heavily influenced by socio-demographic variables. Conclusions - The convergence of both types of data enabled the researcher to reach an in-depth understanding of the issue researched and draw more detailed conclusions. 